\title{
Major Salivary Gland Cancer Clinical Regional Lymph Nodes TNM Finding v8
}

National Cancer Institute

\section{Source}

National Cancer Institute. Major Salivary Gland Cancer Clinical Regional Lymph Nodes

TNM Finding v8. NCI Thesaurus. Code C132764.

A clinical finding about one or more characteristics of major salivary gland cancer, following the rules of the TNM AJCC v8 classification system as they pertain to staging of regional lymph nodes. 